\title{
Leaf morphological and genetic divergence in populations of Drimys (Winteraceae) in Chile
}

\author{
P. Jara-Arancio ${ }^{1,2}$, M.R. Carmona ${ }^{1,3}$, C. Correa ${ }^{4}$, F.A. Squeo ${ }^{1,5,6}$ and \\ G. Arancio ${ }^{1,5}$ \\ 'Instituto de Ecología y Biodiversidad, Facultad de Ciencias, \\ Universidad de Chile, Santiago, Chile \\ ${ }^{2}$ Departamento de Ciencias Biológicas, Facultad de Ciencias Biológicas y \\ Departamento de Ecología y Biodiversidad, Facultad de Ecología y \\ Recursos Naturales, Universidad Andrés Bello, Santiago, Chile \\ ${ }^{3}$ Departamento de Ecología, Pontificia Universidad Católica de Chile, \\ Santiago, Chile \\ ${ }^{4}$ Laboratorio de Biología Evolutiva, Departamento de Ecología \& CASEB, \\ Pontificia Universidad Católica de Chile, Santiago, Chile \\ ${ }^{5}$ Departamento de Biología, Facultad de Ciencias, Universidad de La Serena, \\ La Serena, Chile \\ ${ }^{6}$ Centro de Estudios Avanzados en Zonas Áridas, La Serena, Chile
}

Corresponding author: P. Jara-Arancio

E-mail: pjarancio@gmail.com

Genet. Mol. Res. 11 (1): 229-243 (2012)

Received March 15, 2011

Accepted October 16, 2011

Published February 3, 2012

DOI http://dx.doi.org/10.4238/2012.February.3.3

\begin{abstract}
The genus Drimys is distributed in Chile from semiarid zones to sub-Antarctic forests; there are three species of this tree, $D$. andina, $D$. confertifolia and $D$. winteri, the latter with varieties chilensis and winteri. Northern populations are found in small disjunct natural refuges, specifically mountain cloud forests and the bottom of ravines. The size and continuity of populations are greater in the south, where wetter conditions prevail. Morphological differences between populations have been observed, particularly between the northern populations of Fray Jorge and Talinay. This observation, led to the following questions: a) what is the level of morphological and
\end{abstract}


genetic divergence among the populations of Drimys in Chile? and b) do the populations from Fray Jorge/Talinay, currently classified as $D$. winteri var. chilensis, differ genetically from the other populations of this variety? To answer these questions, we collected leaf samples from 37 populations of all Chilean Drimys, performed leaf morphology analysis and estimated genetic divergence using RAPD markers. We found a high degree of leaf morphological and genetic divergence between the populations of Fray Jorge/Talinay and the other Chilean species of Drimys. The morphological and genetic divergence among varieties of $D$. winteri was greater than that among the species of Drimys, which may indicate problems with their taxonomic classification.

Key words: Drimys; RAPD; Fray Jorge/Talinay; Divergence

\section{INTRODUCTION}

In Chile, the genus Drimys (canelo) is distributed discontinuously from the semi-

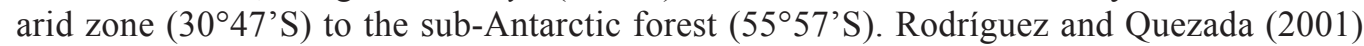
recognized three species in Chile, which are differentiated principally by type of habitat, floral and leaf structures, although there is considerable overlapping of character states. These species are a) Drimys winteri J.R. Forst. and G. Forst., with two varieties: D. winteri var. chilensis (DC) A. Gray, endemic to Chile $\left(30^{\circ} 20^{\prime}\right.$ to $46^{\circ} 25^{\prime}$ 'S) and $D$. winteri var. winteri, endemic to sub-Antarctic forests $\left(45^{\circ} 44^{\prime}\right.$ to $\left.55^{\circ} 58^{\prime} \mathrm{S}\right)$; b) Drimys andina (Reiche) Rodríguez and Quezada (2001), a shrub endemic to sub-Antarctic forests (37 $43^{\circ}$ to $\left.41^{\circ} 34^{\prime} \mathrm{S}\right)$, and c)

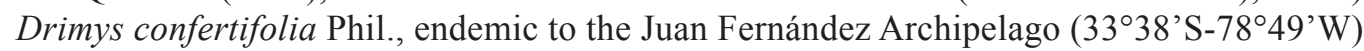
(Rodríguez and Quezada, 2001). Among the populations of D. winteri var. chilensis are two isolated mountaintop populations in Fray Jorge/Talinay whose leaf morphology is highly divergent from the rest of the species of the genus in Chile. These populations date back to the formation, development and paleodistribution of Chilean forests during the Tertiary (Croizat, 1962). Villagrán et al. (2004) suggested that the populations of Fray Jorge/Talinay are the product of a migration before the differentiation of the Chilean-Argentinean species and of the varieties described for D. winteri. In a study of Chilean populations of Drimys from its entire distribution range and analysis of individuals grown in a common garden, we observed a large divergence in leaf morphology both within species and between populations, particularly between the populations of Fray Jorge/Talinay and other populations of D. winteri var. chilensis.

Based on these observations and the background information mentioned above we asked two questions: a) what is the level of genetic and leaf morphological divergence among populations of Drimys in Chile? b) are the populations of Fray Jorge/Talinay genetically differentiated from other populations of $D$. winteri var. chilensis? To answer these questions we collected samples from 37 populations of all Chilean Drimys, performed leaf morphology analysis and estimated genetic divergence using RAPD markers both within and between populations. We also examined the congruence between leaf morphological and genetic divergence. 


\section{MATERIAL AND METHODS}

\section{Study sites}

We collected samples of 32 Chilean populations of $D$. winteri between $30^{\circ} 47^{\prime}$ and $55^{\circ} 57^{\prime}$ S ( 25 of $D$. winteri var. chilensis and seven of $D$. winteri var. winteri). We also collected samples from four populations of $D$. andina (three from Chile and one from Argentina) and one sample of $D$. confertifolia (Robinson Crusoe Island, Archipelago Juan Fernández) (Figure 1 and Table 1).

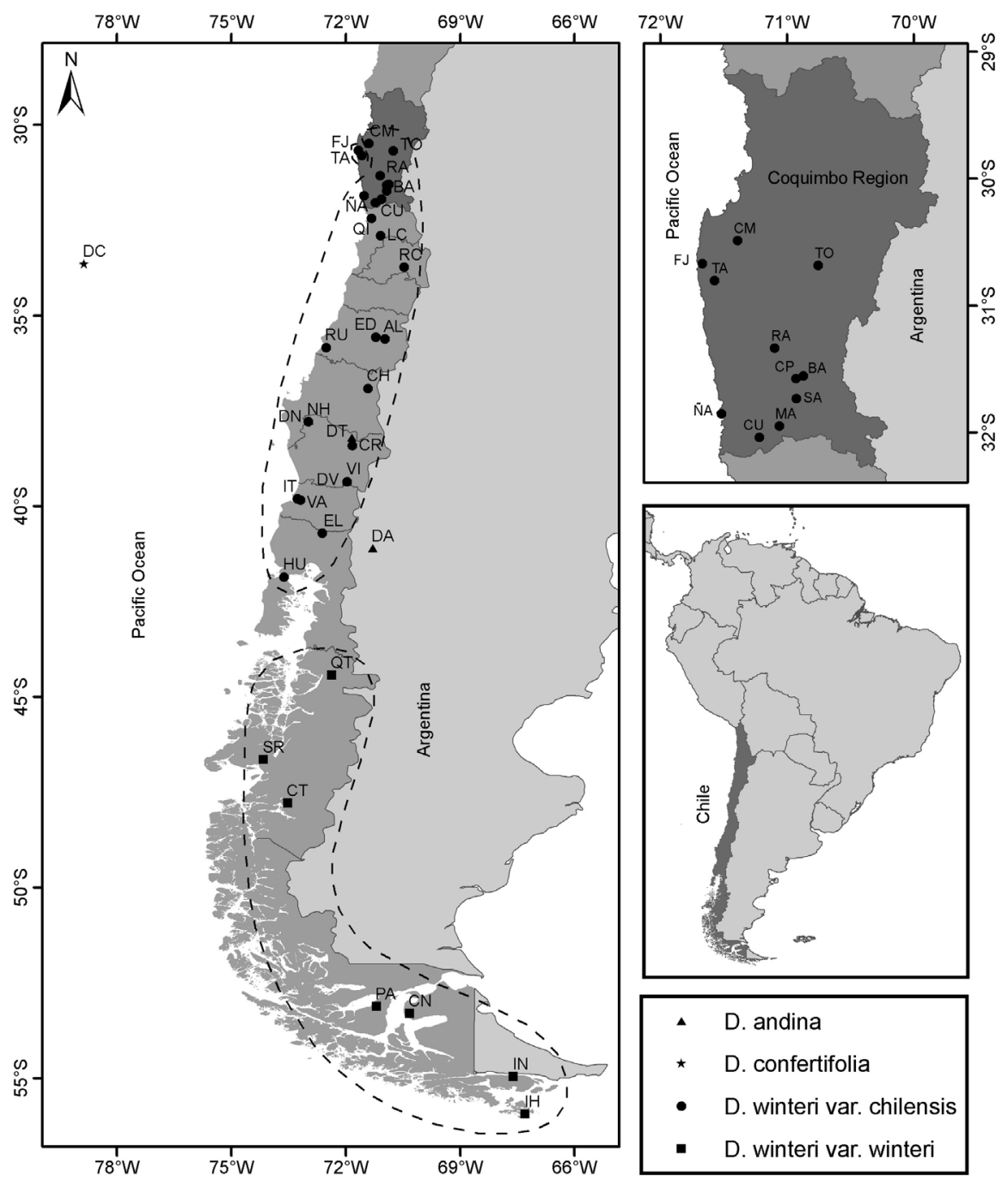

Figure 1. Distribution map of the 37 populations studied of the genus Drimys. The Coquimbo Region, with the 11 populations of $D$. winteri var. chilensis, is amplified at the upper right. Population abbreviations are in Table 1. 


\begin{tabular}{|c|c|c|c|c|c|c|c|c|c|}
\hline \multirow{2}{*}{$\frac{\text { Populations }}{\text { D. winteri var. chilensis }}$} & \multirow[t]{2}{*}{$\mathrm{S}$} & \multirow[t]{2}{*}{$\mathrm{R}$} & \multicolumn{2}{|c|}{ Coordinates } & \multirow{2}{*}{$\frac{\text { Populations }}{\text { Curacautín }}$} & \multirow{2}{*}{$\frac{\mathrm{S}}{\mathrm{CR}}$} & \multirow{2}{*}{$\begin{array}{r}\mathrm{R} \\
\mathrm{IX}\end{array}$} & \multicolumn{2}{|c|}{ Coordinates } \\
\hline & & & & & & & & $38^{\circ} 24^{\prime}$ & $71^{\circ} 49^{\prime}$ \\
\hline Camarones & $\mathrm{CM}$ & IV & $30^{\circ} 29^{\prime}$ & $71^{\circ} 23^{\prime}$ & Villarrica & VI & IX & $39^{\circ} 21^{\prime}$ & $71^{\circ} 57^{\prime}$ \\
\hline Tomé de Rapel & TO & IV & $30^{\circ} 40^{\prime}$ & $70^{\circ} 45^{\prime}$ & Isla Teja & IT & $\mathrm{X}$ & $39^{\circ} 48^{\prime}$ & $73^{\circ} 15^{\prime}$ \\
\hline Fray Jorge & FJ & IV & $30^{\circ} 40^{\prime}$ & $71^{\circ} 39^{\prime}$ & Valdivia & VA & $\mathrm{X}$ & $39^{\circ} 49^{\prime}$ & $73^{\circ} 11^{\prime}$ \\
\hline Talinay & TA & IV & $30^{\circ} 48^{\prime}$ & $71^{\circ} 34^{\prime}$ & Entre Lagos & EL & $\mathrm{X}$ & $40^{\circ} 41^{\prime}$ & $72^{\circ} 37^{\prime}$ \\
\hline Rabanales & RA & IV & $31^{\circ} 20^{\prime}$ & $71^{\circ} 05^{\prime}$ & Hueldén & $\mathrm{HU}$ & $\mathrm{X}$ & $41^{\circ} 51^{\prime}$ & $73^{\circ} 36^{\prime}$ \\
\hline La Capilla & $\mathrm{CP}$ & IV & $31^{\circ} 34^{\prime}$ & $70^{\circ} 55^{\prime}$ & D. winteri var. winteri & & & & \\
\hline El Bato & BA & IV & $31^{\circ} 33^{\prime}$ & $70^{\circ} 52^{\prime}$ & Queulat & QT & XI & $44^{\circ} 25^{\prime}$ & $72^{\circ} 21^{\prime}$ \\
\hline San Agustín & SA & IV & $31^{\circ} 43^{\prime}$ & $70^{\circ} 55^{\prime}$ & San Rafael & SR & XI & $46^{\circ} 38^{\prime}$ & $74^{\circ} 09^{\prime}$ \\
\hline Nague & $\tilde{\mathrm{N}} \mathrm{A}$ & IV & $31^{\circ} 51$ & $71^{\circ} 30^{\prime}$ & Caleta Tortel & $\mathrm{CT}$ & XI & $47^{\circ} 47^{\prime}$ & $73^{\circ} 31^{\prime}$ \\
\hline El Mauro & MA & IV & $31^{\circ} 56^{\prime}$ & $71^{\circ} 03^{\prime}$ & Punta Arenas & PA & XII & $53^{\circ} 06^{\prime}$ & $71^{\circ} 11^{\prime}$ \\
\hline Culimo & $\mathrm{CU}$ & IV & $32^{\circ} 02^{\prime}$ & $71^{\circ} 12^{\prime}$ & Los Canelos & $\mathrm{CN}$ & XII & $53^{\circ} 17^{\prime}$ & $70^{\circ} 19^{\prime}$ \\
\hline Quintero & QI & $\mathrm{V}$ & $32^{\circ} 26^{\prime}$ & $71^{\circ} 19^{\prime}$ & Isla Navarino & IN & XII & $54^{\circ} 56^{\prime}$ & $67^{\circ} 35^{\prime}$ \\
\hline La Campana & $\mathrm{LC}$ & V & $32^{\circ} 53^{\prime}$ & $71^{\circ} 05^{\prime}$ & Isla Hornos & $\mathrm{IH}$ & XII & $55^{\circ} 55^{\prime}$ & $67^{\circ} 17^{\prime}$ \\
\hline Río Clarillo & $\mathrm{RC}$ & RM & $33^{\circ} 43^{\prime}$ & $70^{\circ} 27^{\prime}$ & D. confertifolia and D. andina & & & & \\
\hline Altos de Lircay & $\mathrm{AL}$ & VII & $35^{\circ} 36$ & $70^{\circ} 58^{\prime}$ & D. confertifolia (A.J. Fernández) & DC & V & $33^{\circ} 38^{\prime}$ & $78^{\circ} 51^{\prime}$ \\
\hline El Durazno & ED & VII & $35^{\circ} 34^{\prime}$ & $71^{\circ} 12^{\prime}$ & D. andina (Argentina) & DA & $\mathrm{Ar}$ & $41^{\circ} 06^{\prime}$ & $71^{\circ} 17^{\prime}$ \\
\hline Los Ruiles & RU & VII & $35^{\circ} 50^{\prime}$ & $72^{\circ} 30^{\prime}$ & D. andina (Villarrica) & DV & VIII & $39^{\circ} 21^{\prime}$ & $71^{\circ} 57^{\prime}$ \\
\hline Chillán & $\mathrm{CH}$ & VIII & $36^{\circ} 54^{\prime}$ & $71^{\circ} 24^{\prime}$ & D. andina (Tolhuaca) & DT & IX & $38^{\circ} 12^{\prime}$ & $71^{\circ} 50^{\prime}$ \\
\hline Nahuelbuta & NH & IX & $37^{\circ} 47^{\prime}$ & $72^{\circ} 59^{\prime}$ & D. andina (Nahuelbuta) & DN & IX & $37^{\circ} 45^{\prime}$ & $72^{\circ} 58^{\prime}$ \\
\hline
\end{tabular}

$\mathrm{S}=$ acronym; $\mathrm{R}=$ Chilean political regions (including one population from Argentina $=\mathrm{Ar}$ ).

\section{Leaf morphological analysis}

We randomly collected 10 mature (completely expanded) but not senescent leaves reachable by hand from 10 individuals per population, both from the borders and interior of forests, with a minimum distance of $50 \mathrm{~m}$ between individuals. We studied seven variables of leaf morphology in Drimys: aspect (blade form), roundness (both calibrated by leaf forms established in Hickey and King (1998)), specific weight, thickness, leaf length/ width, and length and width of the petiole. For comparisons we used the median value of each variable per population. To determine differences among populations, we performed three analyses. First, we determined the latitudinal tendency of each variable at the population level using linear regression (SigmaStat 2.0). Second, we performed a cluster analysis (MVSP 3.12). We calculated the Euclidean distance between populations and applied the UPGMA algorithm to construct a dendrogram; to have a critical distance to define significant groups we used the minimum Euclidean distance expected by chance, using the 5\% percentile of the distribution (PopTools 2.7). Finally, we conducted a principal components analysis (PCA).

\section{Molecular analysis}

To estimate the levels of genetic divergence within and between populations of Chilean Drimys we obtained RAPD markers. DNA was extracted from leaf tissue conserved on silica gel, using the protocol of JanBen (1997). To obtain RAPD markers we used the modified protocol of Williams et al. (1990); PCRs used a total volume of $25 \mu \mathrm{L}$, which contained $5 \mu \mathrm{L}$ ADN ( $\approx 5 \mathrm{ng}), 10.8 \mu \mathrm{L}$ purified sterile water, $3.2 \mu \mathrm{L} 25 \mathrm{mM} \mathrm{MgCl}_{2}, 2 \mu \mathrm{L} 10 \mathrm{X}$ buffer, $2 \mu \mathrm{L} 1$ $\mathrm{mM}$ dNTPs (Invitrogen), $1 \mu \mathrm{L} 10 \mu \mathrm{M}$ primer (Invitrogen), and $1 \mu \mathrm{L} 1 \mathrm{U} / \mu \mathrm{L}$ Taq polymerase 
(Promega). PCR was performed in a Mastercycler gradient (Eppendorf) thermocycler, with an initial temperature of $94^{\circ} \mathrm{C}$, followed by 34 cycles of $5 \mathrm{~min}$ of denaturing at $94^{\circ} \mathrm{C}, 1 \mathrm{~min}$ of alignment at $38^{\circ} \mathrm{C}$ and $1 \mathrm{~min}$ of extension at $72^{\circ} \mathrm{C}$, with temperature changes of $1^{\circ}$ per second, and a final extension for $10 \mathrm{~min}$ at $72^{\circ} \mathrm{C}$.

We used 16 primers (see Table 2). PCR products were separated by horizontal electrophoresis at $55 \mathrm{~V}$ for $2 \mathrm{~h}$ and $30 \mathrm{~min}$ on $2 \%$ agarose gels with ethidium bromide in $1 \mathrm{X}$ TBE buffer, $\mathrm{pH}$ 8.0. From the banding patterns we created a binary matrix of the presence/ absence of each band for each individual. We restricted the analysis to 142 fragments (113 polymorphic and 29 monomorphic) with sizes from 141 to $1420 \mathrm{bp}$. With this matrix we performed the following analyses: a) dendrograms (MVSP 3.12): we used the similarity coefficient of Nei and Li (1979) with the UPGMA algorithm, confidence levels were estimated with a bootstrap method with 1000 iterations (FreeTree 0.9.1.5.0); b) principal coordinates analysis (PCO; MVSP 3.12); c) molecular analysis of variance (AMOVA 1.55) at three hierarchic levels: among groups (all species and Fray Jorge/Talinay) $\Phi \mathrm{ct}=\mathrm{S}_{\mathrm{R}}{ }_{\mathrm{R}} /\left(\mathrm{S}^{2}{ }_{\mathrm{w}}+\mathrm{S}_{\mathrm{p}}^{2}+\right.$ $\left.\mathrm{S}_{\mathrm{R}}^{2}\right)$, among populations within groups $\Phi \mathrm{sc}=\mathrm{S}_{\mathrm{p}}^{2} /\left(\mathrm{S}_{\mathrm{w}}^{2}+\mathrm{S}_{\mathrm{p}}^{2}\right)$ and within populations $\Phi \mathrm{st}=$ 1 - ((1 - $\Phi \mathrm{ct}) *(1-\Phi \mathrm{sc}))$, and d) population structure (POPGENE 1.3.2) among populations of $D$. winteri. We estimated the percentage of polymorphic loci, number of genotypes and the Shannon index (Lewontín, 1972). We also applied the correction of Lynch and Milligan (1994) to the matrix obtained to evaluate the effect of using the loci with little variability.

Table 2. Decanucleotide primers (P) used in the RAPD analysis for 37 populations of Drimys.
\begin{tabular}{llllllll}
\hline P & Sequence & P & Sequence & P & Sequence & P & Sequence \\
\hline A01 & CAGGCCCTTC & C07 & CCTGGATTCC & H15 & AATGGCGCAG & O03 & CTGTTGCTAC \\
B14 & TCCGCTCTGG & F06 & GGGAATTCG & M07 & CCGTGACTCA & O10 & TCAGAGCGCC \\
B17 & AGGGAACGAG & F12 & ACGGTACCAG & M13 & GGTGGTCAAG & O16 & TCGGCGGTTC \\
B20 & GGACCCTTAC & H02 & TCGGACGTGA & M17 & TCAGTCCGGG & X07 & GAGCGAGGCT \\
\hline
\end{tabular}

\section{Comparative analysis of leaf morphology and RAPD}

We performed two complementary analyses to evaluate the association among morphological, molecular and geographic variables: a) the Mantel test (MVSP 3.12), comparing the matrixes of genetic, geographic and Euclidean morphological distances, evaluating the statistical significance of the correlation coefficient between each pair of matrixes by a randomization procedure repeated 2000 times, using both tails $\left(\mathrm{P}_{2 \text { tails }}\right)$ (PopTools 2.7), and b) discriminant analysis (MVSP 3.12) to determine the relationship between morphological data and the groups obtained in the genetic analysis.

\section{Reproducibility of RAPD}

Since some authors question the reproducibility of RAPD (Xu et al., 1995; Rieseberg, 1996) we evaluated the confidence of our analysis. We randomly selected 48 samples of the total of 363, dividing them randomly into 16 groups (one primer per group) in which we repeated the analyses with one year old and with recently prepared DNA and chemical components. 


\section{RESULTS}

\section{Leaf morphological analysis}

There were clear latitudinal trends in leaf morphology; leaves of $D$. winteri populations were more oblong, spherical, and thicker, and petioles were longer and thicker the farther south the population was located. Differences in specific weight, however, were not quite significant $(\mathrm{P}=0.062)$ (Figure 2$)$. Three groups of populations were found by cluster analysis: a) $D$. winteri var. winteri with $D$. winteri var. chilensis from Fray Jorge/Talinay, b) $D$. andina with $D$. confertifolia, and c) the other $D$. winteri var. chilensis populations (Figure 3 ). The first two axis of the PCA explained most of the total variance (75.8\%). The varieties of $D$. winteri were somewhat separated on the first axis, whereas $D$. andina and $D$. confertifolia were not separated from the $D$. winteri (Figure 4). On the second axis, the southern most population of $D$. winteri var. winteri (Isla Hornos) and D. winteri var. chilensis from Fray Jorge/Talinay were separated from the other populations, indicating morphological similarities between populations separated by more than $2800 \mathrm{~km}$ (Figure 4).

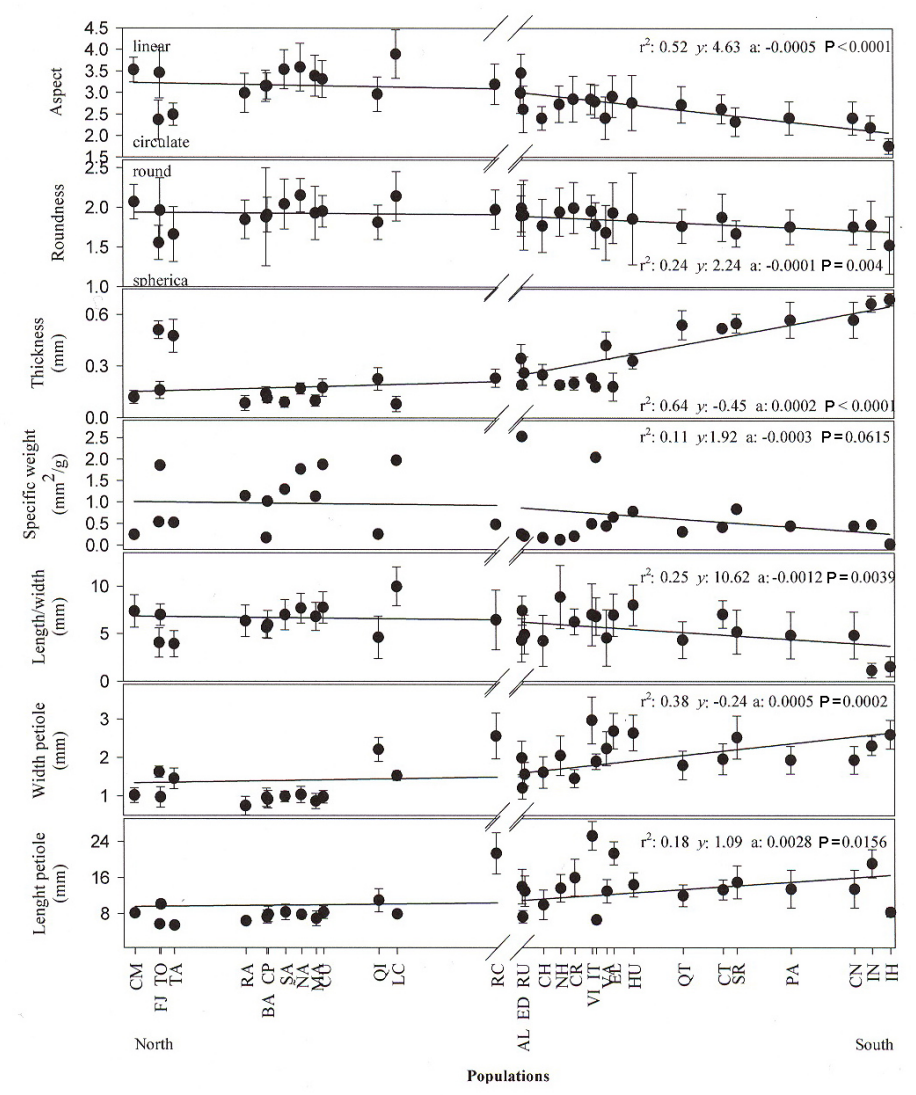

Figure 2. Latitudinal trends leaf morphological of Drimys winteri. Lines show model of linear regression. Values of significance are on the right side. For population abbreviations, see Table 1. 


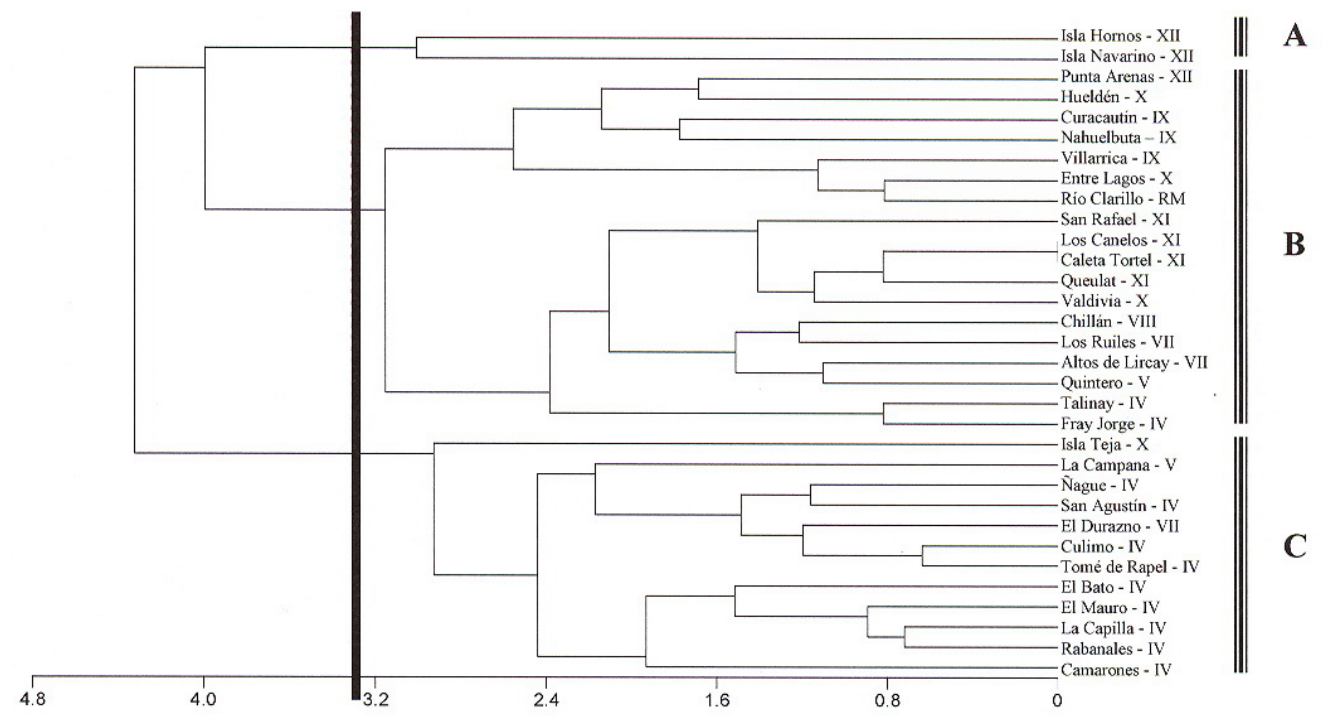

Figure 3. Cluster analysis of Drimys winteri based on seven leaf morphology characters. Line indicates confidence limit, which determines differences between populations. For population abbreviations, see Table 1. A. Isla Hornos and Isla Navarino (XII Region). B. Zone center/Fray Jorge/Talinay. C. Zone center/north/Isla Teja.

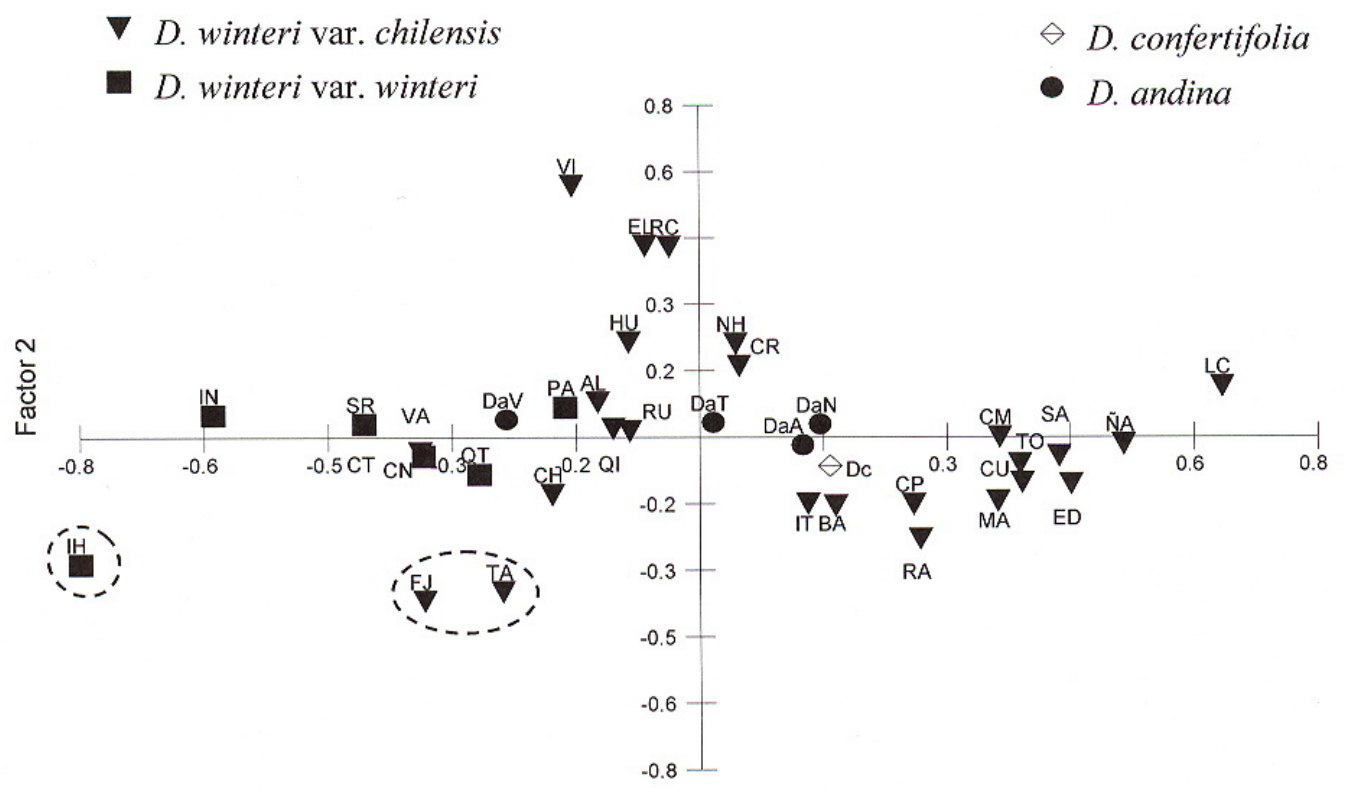

Factor 1

Figure 4. PCA of Drimys based on seven leaf morphology characters. For population abbreviations, see Table 1. 


\section{Molecular analysis}

Based on molecular analysis, the dendrogram for all the 37 populations studied shows a separation between $D$. winteri var. winteri and the rest with $100 \%$ support (Figure 5). Inside of group A, there are potentially three subgroups without support: a) populations from Fray Jorge/Talinay, b) the rest of population of $D$. winteri var. chilensis with respect to $D$. andina and $D$. confertifolia. Finally, $D$. andina is consistently separated from $D$. confertifolia. A detail analysis in D. winteri var. chilensis from Coquimbo Region shows the clear separation of Fray Jorge/Talinay populations from the rest (Figure 6).

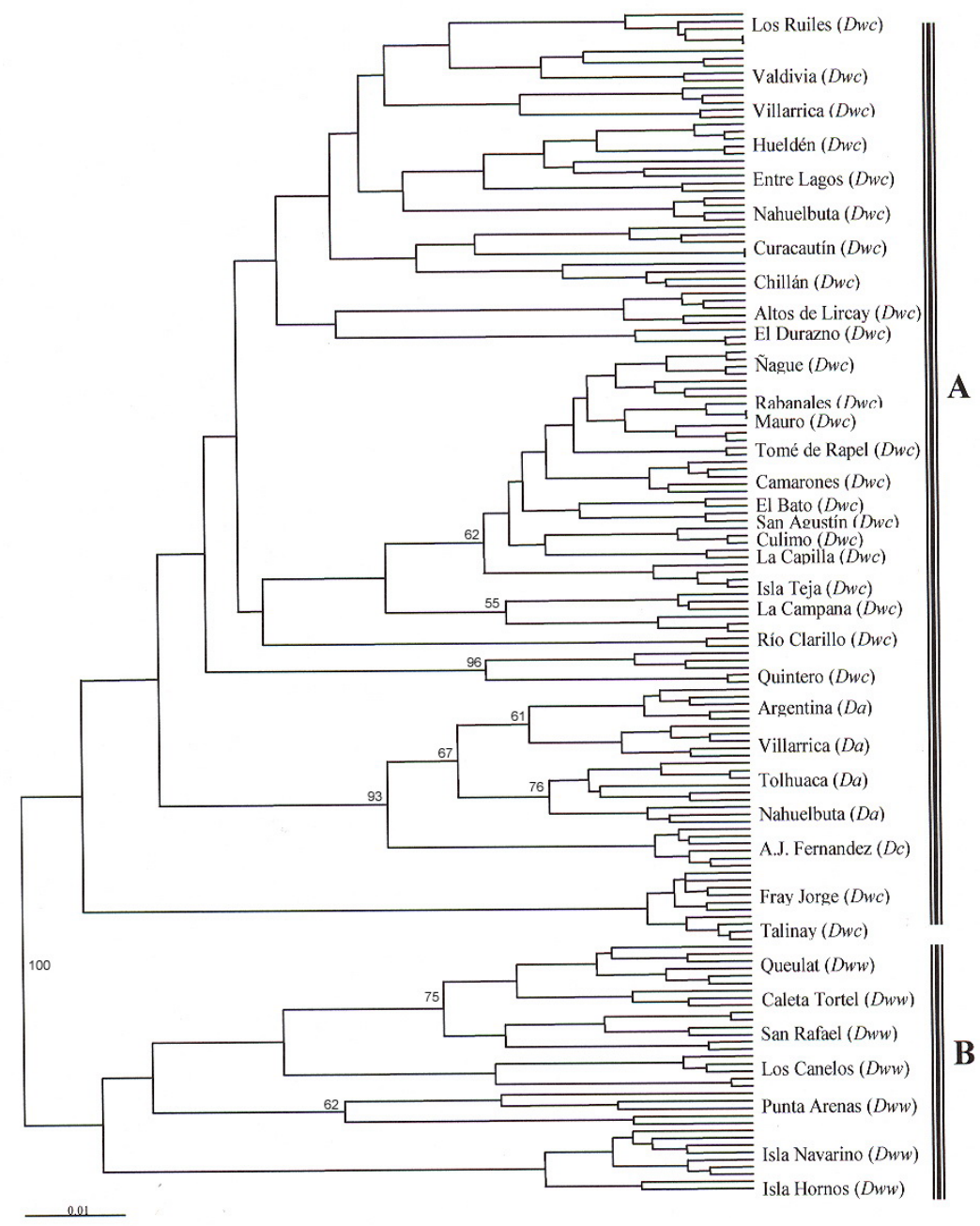

Figure 5. Dendrogram for molecular analyses using RAPD markers generated from Nei and Li (1979) distances using the UPGMA algorithm for populations of Drimys. Bootstrap values above $50 \%$ are shown. A. D. winteri var. chilensis/Fray Jorge-Talinay/D. andina/D. confertifolia. B. D. winteri var. winteri. $D w c=D$. winteri var. chilensis; $D w w=D$. winteri var. winteri; $D a=D$. andina $; c=D$. confertifolia . 


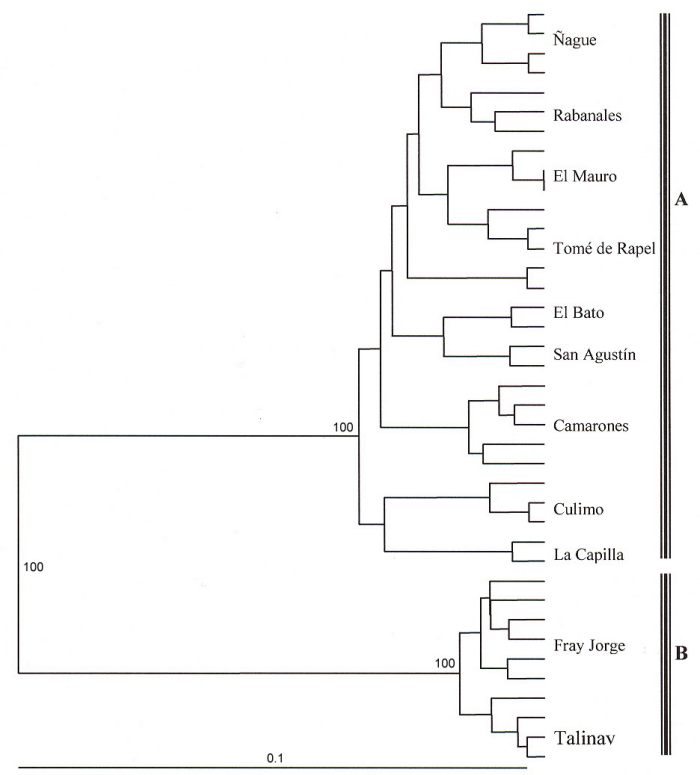

Figure 6. Dendrogram for molecular analyses using RAPD markers generated from Nei and Li (1979) distances using the UPGMA algorithm for 11 populations of Drimys var. chilensis from Coquimbo Region. Bootstrap values above $50 \%$ are shown. A. Nine populations of Drimys var. chilensis from Coquimbo Region. B. Fray Jorge/Talinay.

On the other hand, the PCO shows two groups of populations: 1) D. winteri var. chilensis (including Fray Jorge/Talinay populations), and 2) D. andina, D. confertifolia and $D$. winteri var. winteri (explained the variance of 51.3\%) (Figure 7). Analyzing only the populations of $D$. winteri, the separation among varieties was more evident, with the populations of Fray Jorge/Talinay separated from the rest (explained the variance of 54.4\%) (Figure 8).

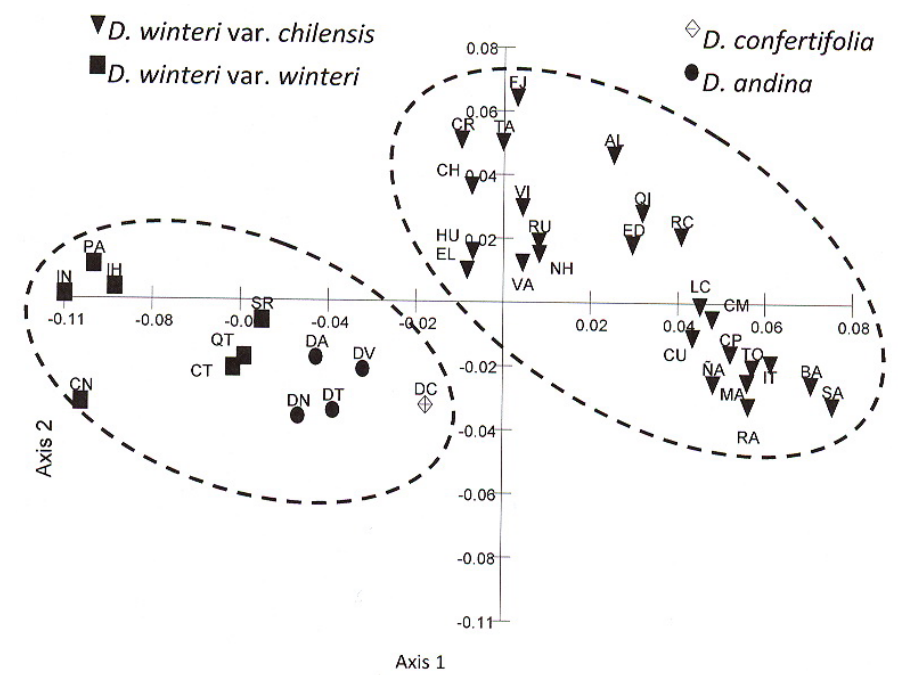

Figure 7. PCO analysis of the species of Drimys based on genetic data. For population abbreviations, see Table 1. 


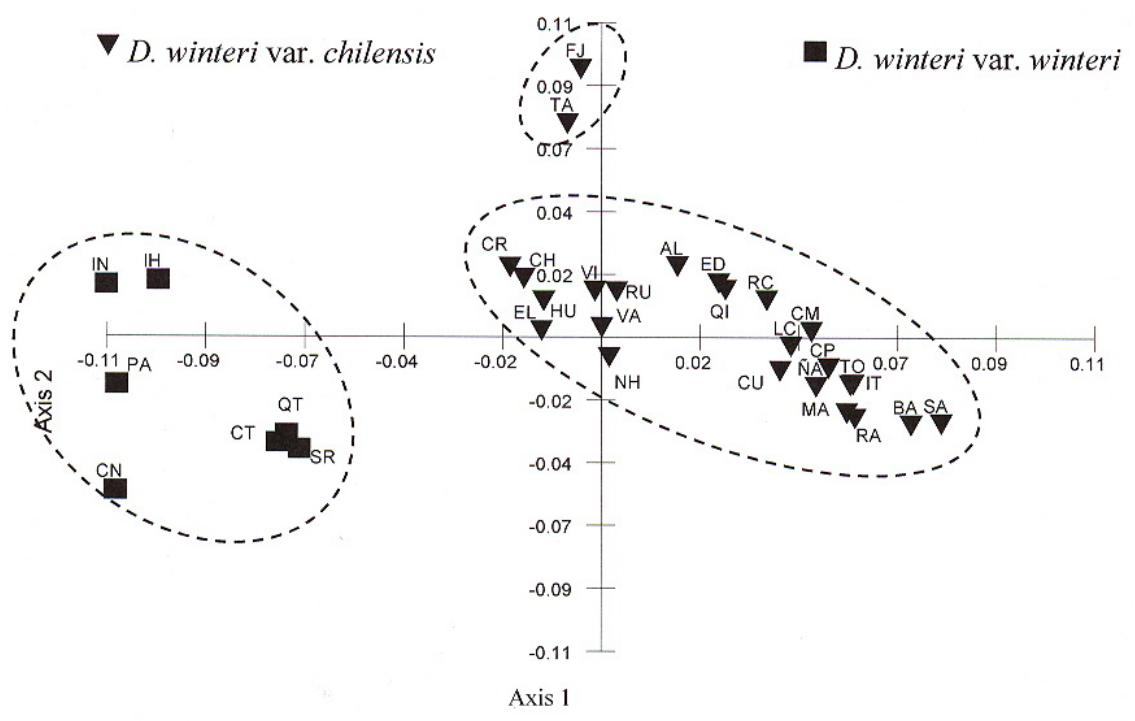

Figure 8. Principal coordinates analysis analysis of Drimys winteri species based on genetic data. For population abbreviations, see Table 1 .

AMOVA found significant differences among all the groups of $D$. winteri and the species of Drimys $(\mathrm{P}<0.001)$. The $\Phi$ statistic values among groups and pairs of groups were all above 0.25 , which by the criterion of Wright (1951) indicates that there is a differentiation at all hierarchical levels (Table 3). Comparing among groups, there was a large genetic differentiation especially between Fray Jorge/Talinay with the rest of $D$. winteri var. chilensis $(0.40)$ and $D$. winteri var. winteri $(0.48)$. There was also considerable differentiation among the varieties of $D$. winteri $(0.35)$.

\begin{tabular}{|c|c|c|c|c|c|}
\hline Variation level & d.f. & Variance & $\%$ total variance & Ф PHI & Statistic \\
\hline \multicolumn{6}{|l|}{ Among varieties of $D$. winteri } \\
\hline Among groups $\left(\mathrm{S}_{\mathrm{p}}^{2}\right)$ & 1 & 6.14 & 35.19 & $(\Phi c t)$ & 0.35 \\
\hline Among populations within groups $\left(\mathrm{S}_{\mathrm{p}}^{2}\right)$ & 29 & 8.06 & 46.17 & (Фsc) & 0.71 \\
\hline Within populations $\left(\mathrm{S}_{\mathrm{w}}^{2}\right)$ & 125 & 3.25 & 18.64 & (Фst) & 0.81 \\
\hline \multicolumn{6}{|c|}{ Populations $D$. winteri from Coquimbo Region } \\
\hline Among groups $\left(\mathrm{S}_{\mathrm{R}}^{2}\right)$ & 1 & 11.28 & 70.55 & (Фct) & 0.71 \\
\hline Among populations within groups $\left(\mathrm{S}_{\mathrm{P}}^{2}\right)$ & 10 & 3.12 & 19.52 & (Фsc) & 0.66 \\
\hline Within populations $\left(\mathrm{S}_{\mathrm{w}}^{2}\right)$ & 38 & 1.59 & 9.92 & (Фst) & 0.90 \\
\hline \multicolumn{6}{|l|}{ Between $\mathrm{FJ} / \mathrm{TA}$ and $D$. winteri var. chilensis } \\
\hline Among groups $\left(\mathrm{S}_{\mathrm{R}}^{2}\right)$ & 1 & 7.08 & 40.25 & $(\Phi c t)$ & 0.40 \\
\hline Among populations within groups $\left(\mathrm{S}_{\mathrm{P}}^{2}\right)$ & 24 & 7.82 & 44.45 & $(\Phi \mathrm{sc})$ & 0.74 \\
\hline Within populations $\left(\mathrm{S}_{\mathrm{w}}^{2}\right)$ & 101 & 2.69 & 15.30 & (Фst) & 0.85 \\
\hline \multicolumn{6}{|l|}{ Between FJ/TA and $D$. winteri var. winteri } \\
\hline Among groups $\left(\mathrm{S}_{\mathrm{R}}^{2}\right)$ & 1 & 9.62 & 47.71 & (Фct) & 0.48 \\
\hline Among populations within groups $\left(\mathrm{S}_{\mathrm{p}}^{2}\right)$ & 8 & 6.91 & 34.26 & (Фsc) & 0.66 \\
\hline Within populations $\left(\mathrm{S}^{2}{ }_{\mathrm{w}}\right)$ & 43 & 3.63 & 18.03 & (Фst) & 0.82 \\
\hline
\end{tabular}

d.f. $=$ degrees of freedom; FJ/TA $=$ Fray Jorge/Talinay. $\Phi c t=$ variance component of groups with respect to the total variance; $\Phi s c=$ variance component within groups with respect to variance among populations; $\Phi$ st $=$ variance component among populations with respect to the total variance. 
Finally, the analysis of population structure revealed a tendency to increase the percentage of polymorphic loci, number of genotypes and the Shannon index towards the south (Figure 9).

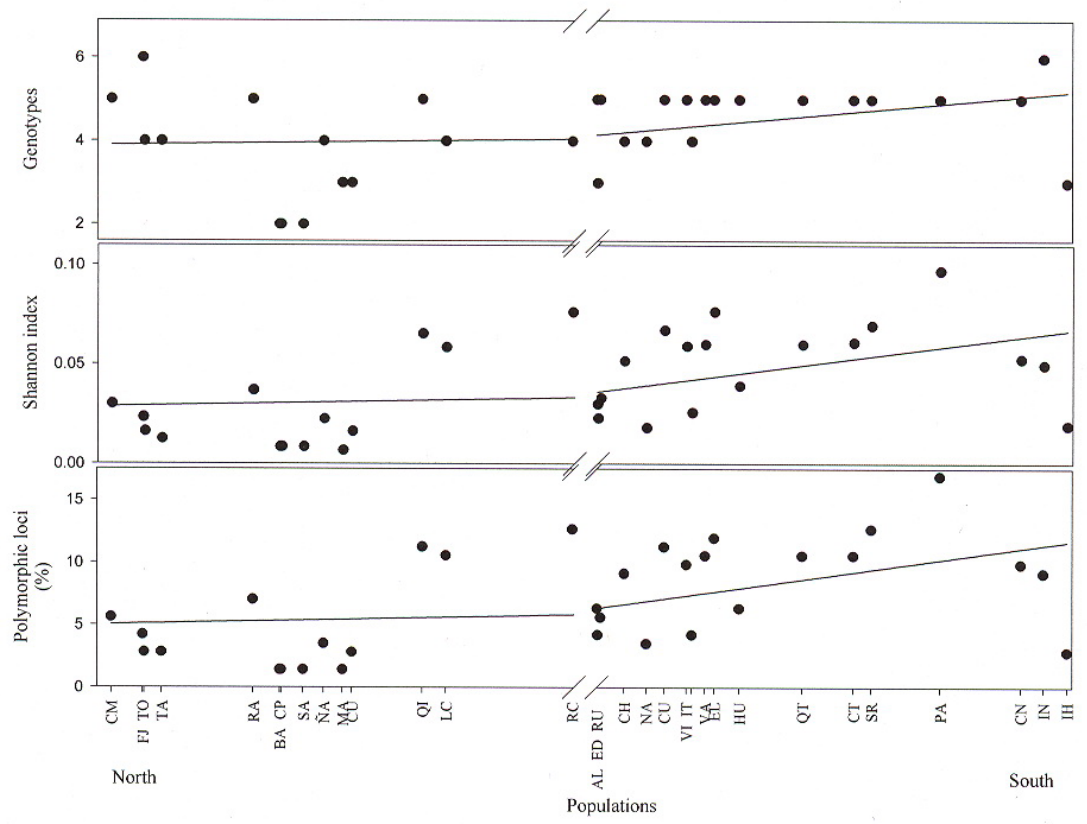

Figure 9. Analysis of the species of Drimys winteri, based on genetic data, revealed latitudinal trends to increase the percent polymorphic loci, number of genotypes and the Shannon index towards the south. For population abbreviations, see Table 1 .

\section{Comparative analysis of leaf morphology and RAPD}

The Mantel test indicated that at the species-level there was a positive and significant association among leaf morphological, genetic and geographic distances. That is, the greater the geographic distance between populations, the greater the morphological divergence $(\mathrm{r}=$ $\left.0.196 ; \mathrm{P}_{2 \text { tails }}=0.031\right)$ and the genetic divergence $\left(\mathrm{r}=0.381 ; \mathrm{P}_{2 \text { tails }}<0.001\right)$, and greater genetic divergence is accompanied by greater morphological divergence $\left(\mathrm{r}=0.119 ; \mathrm{P}_{2 \text { tails }}=0.032\right)$. The discriminant analysis classified correctly $86 \%$ of the individuals in the populations of $D$. winteri and $81 \%$ were correctly classified to species. The percentages of incorrect classification are due to the populations of Fray Jorge/Talinay, which are not in the group of $D$. winteri var. chilensis, and to the fact that $D$. andina and $D$. confertifolia did not disassociate.

\section{Correction of Lynch and Milligan (1994) and analysis of reproducibility}

The correction of Lynch and Milligan (1994) reduced the bands from 142 to 92, with which we obtained results equivalent to those described above. The reproducibility was $93.75 \%$. 


\section{DISCUSSION}

Currently, the populations of Drimys have a disjunct distribution in Chile, especially in the northern part of its distribution. This disjunction has been explained by fragmentation of the west coastal strip along the subtropical South America that occurred during the Miocene (Villagrán et al., 2004), and by the intensification of aridity due to the formation of the Arid Diagonal (Garzione et al., 2008). Maldonado and Villagrán (2001) documented expansions and contractions of the formation Luma chequen, Escallonia revoluta and D. winteri of the Ñague forest, located in southern Coquimbo Region, over the last 5300 years, associated with changes in the water table produced by regional variation in precipitations. These authors also found that during the last 10,000 years the extension of these forests has been considerably reduced due to human activity.

One of the largest genetic divergences found was among the varieties of $D$. winteri that may be attributed principally to the arid conditions, which fragmented its habitat and eliminated gene flow, forcing the populations to evolve independently. However, at the within population level, Shannon's divergence index in D. winteri varied from 0.007 (El Mauro "MA", at $32^{\circ} \mathrm{S}$ ) to 0.097 (Punta Arenas "PA", at 50 $\mathrm{S}$ ), with a mean of 0.04 . This value is much lower than those found for other species, which inhabit the same areas; Aextoxicon punctatum, 0.36 (Nuñez-Ávila and Armesto, 2006); Araucaria araucana, 0.65 (Bekessy et al., 2002); Fitzroya cupressoides, 0.54 (Allnutt et al., 1999); Podocarpus salignus, 0.64 (Allnutt et al., 2001); Pilgerodendron uviferum, 0.57 (Allnutt et al., 2003), and Populus tremuloides, 0.65 (Yeh et al., 1995). This difference may be due to the form of propagation of Drimys, which is mainly vegetative due to poor seed germination (Figueroa and Castro, 2002) or to high mortality of young plants within the small forests. This clonal reproduction would impede recombination and the increase in the gene pool.

The greatest genetic and leaf divergence was found between Fray Jorge/Talinay and the rest of the populations studied. A similar result was reported for A. punctatum by Nuñez-Ávila and Armesto (2006), who found high genetic divergence between the relict forests of northcentral Chile (Fray Jorge/Santa Inés) and the rest of the populations of this Chilean species. Fray Jorge is the northernmost forest in Chile; it is a relict forest of hygrophilic vegetation in an area of arid shrublands, which is maintained by fog condensation (Squeo et al., 2004, 2005). This forest has a floristic similarity with the temperate rainforests of the Valdivian and northPatagonian type in southern Chile and with the continental and oceanic islands of the Chilean (Pacific) coast (Villagrán et al., 2004); it appears to be a relict of the ancient biota, which populated Chile. Croizat (1962) concludes that the origin of the Fray Jorge flora is linked to the formation, development and paleodistribution of forests in Chile during the Tertiary. The genetic divergences found between the Fray Jorge/Talinay populations compared with other $D$. winteri var. chilensis $(\Phi=0.40)$ and $D$. winteri var. winteri $(\Phi=0.48)$ are very high compared to the other divergences that we found within and between species of Drimys, which were all less than 0.34 . The genetic divergences between the populations of Fray Jorge/Talinay and other populations of $D$. winteri var. chilensis from north-central and southern Chile suggest two phenomena: first, an early separation of Fray Jorge/Talinay populations associated with the slow tectonic lift of the Alturas de Talinay, which includes the forests of Fray Jorge, Talinay and Santa Inés, during the early to middle Pleistocene. This is consistent with Villagrán et al. (2004) who suggested that Fray Jorge is the product of a migration, which was produced 
before the differentiation of the Chilean and Argentinean species and the described varieties of D. winteri. Currently, these relict forests are isolated and persist at the tops of coastal mountains due mainly to the fog they intercept, which may provide up to $1000 \mathrm{~mm}$ annual precipitation to the forests (Pérez and Villagrán, 1994). Additionally, a secondary colonization of other populations located in the Coquimbo Region from south-central Chile occurred later. No evidence of recent gene flow between these two groups of populations exists. The high genetic divergence may be influenced by isolation, which impedes gene flow and favors independent population evolution (Grant, 1998; Traveset, 2001).

Our results are in discrepancy with the current classification of the genus by Rodríguez and Quezada (2001). The information we present opens a large number of questions, especially concerning the origin of the populations of Drimys in Chile and the antiquity of the populations of Fray Jorge/Talinay. Our results may be the base for a new phylogenetic study, which will help answer these questions and re-evaluate the classification of the genus Drimys in Chile.

There have been several published phylogenetic studies of Drimys; however, these present some limitations, such as incomplete phylogenies where only one or two species were used (Suh et al., 1993; Karol et al., 2000; Doust and Drinnan, 2004), or lack of robustness in the nodes, such as the study of Ruiz et al. (2008). These authors used a nuclear gene and concluded that the genus Drimys is monophyletic, but found no support for internal resolution between species. Another study with nuclear and plastid genes at the family level estimated that the divergence between Drimys and its sister clade Pseudowintera + Zygogynum s.l. occurred in the Cretaceous, but the divergence between the two subclades of Drimys (D. roraimensis, $D$. brasiliensis, $D$. angustifolia, $D$. granadensis, $D$. confertifolia, $D$. winteri, $D$. andina) occurred from 18.5-15.5 Ma (Marquínez et al., 2009). This range of dates coincides with the formation of the South American Arid Diagonal, which increased the aridity in the north-central and north Chile; this event dates back to at least the upper Miocene, when the Andes reached sufficient height to generate an effective block to the eastern winds and increase the vigor of the cold Humboldt current and the South Pacific Subtropical Anticyclone (Zachos et al., 2001; Strecker et al., 2007; Garzione et al., 2008). The elevation of the Andes to its current condition dates back to $15 \mathrm{Ma}$ (Alpers and Brimhall, 1988) or $10 \mathrm{Ma}$ (Gregory-Wodzicki, 2000), coinciding with the divergence times within the genus Drimys. These dates also coincide with the origin or divergence of other taxa associated with increased aridity: i) Chuquiraga, whose origin and diversification is associated with the elevation of the Andes at the end of the Tertiary and with the climatic fluctuations of the Pleistocene and Holocene (Ezcurra, 2002); ii) Malesherbiaceae, which originated in the late Miocene or early Pliocene (Gengler-Nowak, 2002), iii) Chaetanthera, whose ancestor lived in the lowlands, in the Miocene-Pliocene it took refuge in highlands (Hershkovitz et al., 2006a); iv) Tropaeolum section Chilensia, whose divergence is associated with its environment becoming more arid in the middle Miocene (Hershkovitz et al., 2006b); v) Heliotropium section Cochranea, which diverged between the Miocene and Pliocene (Luebert and Wen, 2008) and vi) Schizanthus, which diverged in the Pliocene (Pérez et al., 2006).

\section{ACKNOWLEDGMENTS}

A special thank to CONAF. We thank the herbaria ULS, CONC, SGO, M.A. Hershkovitz, Mélica Muñoz, Mary Kalin Arroyo, Eduardo Soto, Rafael Guevara and Andrea Loayza, 
and the Biology Department of Universidad de La Serena and the Ecology Department of the Universidad de Chile. This study is part of a Master's thesis in Ecology of Arid Zones, presented by P. Jara-Arancio to the University of La Serena. This is a contribution to the research program of Senda Darwin Biological Station, Chiloe, Chile. P. Jara-Arancio was the recipient of a postdoctoral fellowship from IEB, ICM P05-002, PFB-23.

\section{REFERENCES}

Allnutt TR, Newton AC, Lara A, Premoli A, et al. (1999). Genetic variation in Fitzroya cupressoides (alerce), a threatened South American conifer. Mol. Ecol. 8: 975-987.

Allnutt TR, Courtis JR, Gardner M and Newton AC (2001). Genetic variation and wild Chilean and cultivated British populations of Podocarpus salignus D. Don (Podocarpaceae). Edinb. J. Bot. 58: 459-473.

Allnutt TR, Newton AC, Premoli A and Lara A (2003). Genetic variation in the threatened South American conifer Pilgerodendron uviferum (Cupressaceae), detected using RAPD markers. Biol. Conserv. 114: 245-253.

Alpers CN and Brimhall GH (1988). Middle miocene climatic change in the Atacama Desert, northern Chile: evidence from supergene mineralization at La Escondida. Geol. Soc. Am. Bull. 100: 1640-1656.

Bekessy SA, Allnutt TR, Premoli AC, Lara A, et al. (2002). Genetic variation in the vulnerable and endemic Monkey Puzzle tree, detected using RAPDs. Heredity 88: 243-249.

Croizat L (1962). On the age of Fray Jorge and Talinay in Chile. Rev. Univ. 47: 57-61.

Doust AN and Drinnan AN (2004). Floral development and molecular phylogeny support the generic status of Tasmannia (Winteraceae). Am. J. Bot. 91: 321-331.

Ezcurra C (2002). Phylogeny, morphology and biogeography of Chuquiraga an Andean-Patagonian genus of AsteraceaeBarnadesioideae. Bot. Rev. 68: 153-170

Figueroa JA and Castro S (2002). Effects of bird ingestion on seed germination of four woody species of the temperate rainforest of Chiloé island, Chile. Plant Ecol. 160: 17-23.

Garzione CN, Hoke GD, Libarkin JC, Withers S, et al. (2008). Rise of the Andes. Science 320: 1304-1307.

Gengler-Nowak K (2002). Reconstruction of the biogeographical history of Malesherbiaceae. Bot. Rev. 68: 171-188.

Grant PR (1998). Evolutions on Islands. Oxford University Press, Oxford.

Gregory-Wodzicki KM (2000). Uplift history of the central and Northern Andes: A review. Geol. Soc. Am. Bull. 112; 1091-1105.

Hershkovitz MA, Arroyo MT, Bell C and Hinojosa LF (2006a). Phylogeny of Chaetanthera (Asteraceae: Mutisieae) reveals both ancient and recent origins of the high elevation lineages. Mol. Phylogenet. Evol. 41: 594-605.

Hershkovitz MA, Hernández-Pellicer CC and Arroyo MTK (2006b). Ribosomal DNA evidence for the diversification of Tropaeolum sect. Chilensia (Tropaeolacea). Plant Syst. Evol. 260: 1-24.

Hickey M and King C (1998). Common Families of Flowering Plants. University Cambridge Press, Cambridge.

JanBen (1997). DNeasy Plant Mini Kit and DNeasy Plant Maxi Kit. Handbook for DNA Isolation from Plant Tissue. QIAGEN Company 2003-2012.

Karol KG, Suh Y, Schatz GE and Zimmer EA (2000). Molecular evidence for the position of Takthajania in the Winteraceae: inference from nuclear ribosomal and chloroplast gene spacer sequences. Ann. Mo. Bot. Gard. 87: 414-432.

Lewontin RC (1972). The apportionment of human diversity. Evol. Biol. 6: 381-398.

Luebert F and Wen J (2008). Phylogenetic analysis and evolutionary diversification of Heliotropium Sect. Cochranea (Heliotropiaceae) in the Atacama Desert. Syst. Bot. 33: 390-402.

Lynch M and Milligan BG (1994). Analysis of population genetic structure with RAPD markers. Mol. Ecol. 3: 91-99.

Maldonado A and Villagrán C (2001). Historia del Bosque Pantanoso de Ñague, Costas de Los Vilos (IV Región, Chile) y sus Relaciones con los Cambios Paleoambientales de los Últimos 5,300 años. In: Libro Rojo de la Flora Nativa y de los Sitios Prioritarios para su Conservación: Región de Coquimbo (Squeo FA, Arancio G and Gutiérrez JR, eds.). Ediciones Universidad de La Serena, La Serena, 261-272.

Marquínez X, Lohmann LG, Salatino ML, Salatino A, et al. (2009). Generic relationships and dating of lineages in Winteraceae based on nuclear (ITS) and plastid (rpS16 and psbA-trnH) sequence data. Mol. Phylogenet. Evol. 53: 435-449.

Nei M and Li WH (1979). Mathematical model for studying genetic variation in terms of restriction endonucleases. Proc. Natl. Acad. Sci. U. S. A. 76: 5269-5273.

Nuñez-Ávila M and Armesto JJ (2006). Relict islands of temperate rainforest tree Aextoxicon punctatum (Aextoxicaceae) 
in semi-arid Chile: genetic diversity and biogeographic history. Aust. J. Bot. 54: 733-743.

Pérez C and Villagrán C (1994). Influencia del clima en el cambio florístico, vegetacional y edáfico de los bosques de olivillo (Aextoxicon punctatum R. et Pav.) de la Cordillera de la Costa de Chile: implicancias biogeográficas. Rev. Chil. Hist. Nat. 67: 77-88.

Pérez F, Arroyo MT, Medel R and Hershkovitz MA (2006). Ancestral reconstruction of flower morphology and pollination systems in Schizanthus (Solanaceae). Am. J. Bot. 93: 1029-1038.

Rieseberg LH (1996). Homology among RAPD fragments in interspecific comparisons. Mol. Ecol. 5: 99-105.

Rodríguez R and Quezada M (2001). Flora de Chile Winteraceae-Ranunculaceae. Universidad de Concepción, Concepción.

Ruiz E, Toro O, Crawford DJ, Stuessy TF, et al. (2008). Phylogenetic relationships among Chilean species of Drimys (Winteraceae), based on ITS sequences and insertion/deletion events. Gayana Bot. 65: 220-228.

Squeo FA, Pizarro-Araya J and Vega S (2004). Ecofisiología del Bosque Relicto de Aextoxicon punctatum (Olivillo) en el Parque Nacional Bosque Fray Jorge, Coquimbo. In: Historia Natural del Parque Nacional Bosque Fray Jorge (Squeo FA, Gutiérrez JR and Hernández IR, eds.). Ediciones Universidad de La Serena, La Serena, 219-234.

Squeo FA, Arancio G and Novoa JE (2005). Área, Exposición y Caracterización Florística del Bosque Relicto de Fray Jorge, Coquimbo, Chile. In: Historia, Biodiversidad y Ecología de los Bosques Costeros de Chile (Smith-Ramírez C, Armesto J and Valdovinos C, eds.). Editorial Universitaria, Santiago, 120-133.

Strecker MR, Alonso RN, Bookhagen B, Carrapa B, et al. (2007). Tectonics and climate of the Southern Central Andes. Annu. Rev. Earth Planet Sci. 35: 747-787.

Suh Y, Thien LB, Reeve HE and Zimmer EA (1993). Molecular evolution and phylogenetic implications of internal transcribed spacer sequences of phylogeny of ribosomal DNA in Winteraceae. Am. J. Bot. 80: 1042-1055.

Traveset A (2001). Ecología Reproductiva de Plantas en Condiciones de Insularidad: Consecuencias Ecológicas y Evolutivas del Aislamiento Geográfico. In: Ecosistemas Mediterráneos, Análisis Funcional (Zamora R and Pugnaire FJ, eds.). Textos Universitarios CSIC-AEET, Madrid, 269-289.

Villagrán C, Armesto JJ, Hinojosa LF, Cuvertino J, et al. (2004). El Enigmático Origen del Bosque Relicto de Fray Jorge. Historia Natural del Parque Nacional Bosque Fray Jorge. Ediciones Universidad de La Serena, La Serena, 3-43.

Williams JG, Kubelik AR, Livak KJ, Rafalski JA, et al. (1990). DNA polymorphisms amplified by arbitrary primers are useful as genetic markers. Nucleic Acids Res. 18: 6531-6535.

Wright S (1951). The genetical structure of populations. Ann. Eug. 15: 323-354.

Xu H, Wilson DJ, Arusekar S and Bakalinsky AT (1995). Sequense-specific polymerase chain reaction markers derived from randomly amplified polymorphic DNA markers for fingerprinting grape (Vitis) rootstocks. J. Am. Soc. Hort. Sci. 120: 714-720.

Yeh FC, Chong DKX and Yang RC (1995). RAPD variation within and among natural populations of trembling aspen (Populus tremuloides Michx.) from Alberta. J. Hered. 86: 454-460.

Zachos J, Pagani M, Sloan L, Thomas E, et al. (2001). Trends, rhythms, and aberrations in global climate 65 Ma to present. Science 282: 686-693. 